\title{
Titles Received
}

If you would like to review one of these books, please submit a request to the book review editor Thomas M. Bender, M.D., at lq@cathmed.org

Dimech-Juchniewicz, Jean. Facing Infertility: A Catholic Approach, with a foreword by Paul Carpentier, M.D. Boston: Pauline Books \& Media, 2012. xiii+ 192 pp.

Tranzillo, Jeffrey. John Paul II on the Vulnerable. Washington, D.C.: The Catholic University of America Press, 2013.

Veatch, Robert M. Hippocratic, Religious, and Secular Medical Ethics: The Points of Conflict. Washington, D.C.: Georgetown University Press, 2012. 